\title{
Ergonomic Analysis of Tele-operation Tasks and Remote Handling Devices for a Pyroprocessing Facility
}

\author{
Seung Nam Yu, Jong Kwang Lee, Sung Hyun Kim, Byung Suk Park, Ki Ho Kim, Il Je Cho \\ Remote System Technology Development Section, Korea Atomic Energy Research Institute, \\ Daejeon, 305-353, Korea
}

\begin{abstract}
Objective: The aim of this study is ergonomic analysis of tele-operation tasks using modified remote handling devices dedicated to the cell of PRIDE(PyRoprocess Integrated inactive DEmonstration facility) in KAERI(Korea Atomic Energy Research Institute). Background: Tele-operation manipulators of the PRIDE are applied to perform the remote handling and management of pyroprocessing facilities. Generally, these kinds of systems are composed of master-slave system and its peripherals installed along a wall or ceiling of the cell, and the manipulators transmit the user's own motion to grippers directly. However, a user convenience and intuitiveness while operating the manipulators have not been fully considered in research fields. Method: This study tries to analyze the ergonomic performance of remote handling manipulators in the developed cell facility. It was included that the analysis of operator's capability for his/her own motion range of upper arm while manipulating the MSM, considerations of its manipulation margin and related tool modifications to improve the remote handling performance. Conclusion: The test results of several remote handling tasks performed in PRIDE are represented, and adequate operation strategies for the tele-operation system of hot-cell type facilities are proposed. Application: The knowledge represented in this study can be utilized to improve a tele-operation system operated in a large-scale hot-cell system.
\end{abstract}

Keywords: Tele-operation system, Pyroprocessing, Remote handling system, Master-slave system

\section{Introduction}

원자력 분야에서는 핫셀(Hot cell)이나 아르곤 셀(Ar cell) 등과 같이 특수한 환경에서 운용되는 공정장치의 운전 및 유지보수를 위해서 원격조작기가 널리 활용되고 있다. 이러한 원격조작기는 일반적으로 Master-Slave 시스템으 로 이루어져 있고, 구조적 단순화 및 운전 편의성을 위하여 Master와 Slave가 동일한 기구학적 구조로 구성된다는 특 징을 가지고 있다. 원격 취급 기술과 관련하여 지금까지 다 양한 조작기들이 개발되어 왔으며, 이와 관련한 원격 기술은
방사선 작업자의 피폭을 감소시키고 작업의 신뢰성을 높일 수 있는 기술로 인식되고 있다(Rennich, 2006 and Pittman, 1999). 특히 노후 시설 해체, 사용 후 연료 및 방사성폐기물 관리, 원전 노심 유지보수 등 원자력 분야뿐만 아니라 다양 한 분야의 극한 환경에 대응할 수 있는 기술로 인정받고 있 다(H.S. Lee, 2009). 하지만 일부 서보(Servo) 형 원격조작 기들을 제외한 대부분의 원격조작기들은, Slave 시스템 말단 에 위치한 대상물에 대해서 조작자 자신의 근력을 상당 부분 사용하여 취급해야만 한다. 특히 조작기를 통한 원격 취급 작업은 작업자의 손으로 직접 대상물을 취급하는 작업이상 으로 높은 작업부하와 숙련도를 요구하기도 한다(Yu, 2012).

Corresponding Author: Seung-Nam Yu. Remote System Technology Development Section, Korea Atomic Energy Research Institute, Daejeon, 305-353, Korea. Phone: +82-42-868-4502, E-mail: snyu@kaeri.re.kr Copyright@2013 by Ergonomics Society of Korea(pISSN:1229-1684 eISSN:2093-8462). All right reserved.

(c) This is an open-access article distributed under the terms of the Creative Commons Attribution Non-Commercial License(http://creativecommons.org/licenses/by-nc/3.0/), which permits unrestricted non-commercial use, distribution, and reproduction in any medium, provided the original work is properly cited. http://www.esk.or.kr 


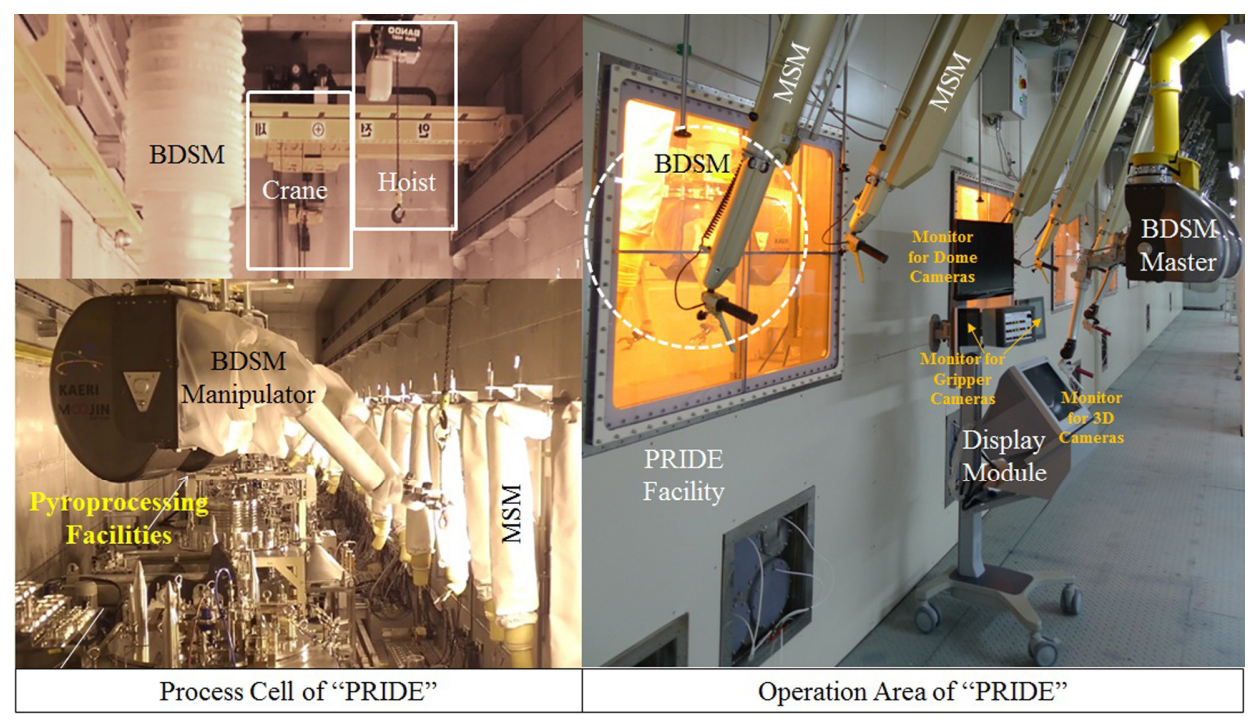

Figure 1. Operation(Outside) and Process (Inside) area of pyroprocessing facility

따라서 원격조작기를 운영하는 환경에 대해서, 일반 산업현 장에 상응하는 작업부하 및 작업 환경에 대한 인간공학적 분석이 필요하리라 판단된다. 본 연구에서는 2012년을 기 점으로 구축된 PRIDE(PyRoprocess Integrated inactive DEmonstration facility, 아르곤 셀 기반의 파이로 건식처리 일관공정 시험시설, Figure 1 참조)를 대상으로 하여 작업자 의 원격조작기 운전조건을 분석하는 한편, 셀 내부 관찰을 위해 마련된 작업창에서의 시야 확보를 고려하여 시뮬레이 션을 통해 장치배치를 수행하였다. 또한 산업현장에서 일반 적으로 사용되는 공구 및 인양장비를 원격 취급 작업에 유 리하도록 개선한 사례들을 제시하고, 이들을 활용하여 실제 PRIDE 셀 내부에서의 원격 모듈교체 작업을 시연하였다. 최종적으로 원격 취급 실험 결과를 바탕으로 현재의 원격 취 급 프로세스의 현황을 고찰하고 향후 개선사항을 제시하였 다. PRIDE는 세계 최초로 구현된 공학규모 파이로공정 실 증시설로서, 기존의 일반적인 핫셀을 상회하는 규모를 가지 고 있다. 따라서 본 연구에서 제시된 일련의 분석들은 기존 유사시설의 개량보다는 새로운 형태의 시설에 대한 Pilot Research의 관점에서 수행되었음을 밝혀둔다. 이 논문에서 다뤄지는 원격조작기들은 전세계적으로 널리 활용되고 있 는 기계식 원격조작기(MSM, Master-Slave Manipulator, $\mathrm{HWM}$ 社 제품) 와 한국원자력연구원에서 개발한 서보형 원격 조작기인 $\mathrm{BDSM}$ (Bridge Transport System for Dual-Arm Servo-Manipulator)을 대상으로 하였다. 자세한 PRIDE 시스템의 특징 및 시스템 구성은 $\operatorname{Kim}(2012)$ 과 Lee(2011) 의 논문을 참조하기 바란다.

\section{System Configuration}

대상 원격조작기 시스템은 셀 외벽 부착형 MSM 및 셀 내부 천정 이동형 $\mathrm{BDSM}$ 으로 구성되어 있다. MSM의 Arm 은 한팔 6 자유도, 양팔 합계 총 12 자유도로 구성되어 있고, 작업창 부근에 위치한 장치 및 작업 대상물을 주로 취급한다. $\mathrm{BDSM}$ 의 $\mathrm{Arm}$ 은 한팔 7자유도, 양팔 합계 총 14 자유도로 구성되어 있으며, Telescopic Tube를 통해 천정이동장치와 연결되어 있다. BDSM은 천정이동장치를 통하여 PRIDE 내 부 공간을 자유롭게 이동할 수 있으며, 목표 지점에 위치한 후에는 양팔 서보형 조작기의 자체 자유도를 활용하여 정교 한 작업을 수행할 수 있다. Figure 2에서와 같이 조작자는 작업창을 통해 셀 내부 공정장치 및 원격조작기의 동작을 관찰할 수 있지만, 경우에 따라서는 장애물로 인하여 특정 지점의 육안 관찰에 어려움이 있을 수 있다. 이를 보완하기 위해 셀 내부에 설치된 별도의 카메라를 통해 제공되는 영상 정보를 활용하여 시스템의 거동이나 원격 취급 대상의 사각 지대를 관찰할 수 있다.

\section{Considerations of Manipulation Convenience for Remote Handling Tasks in PRIDE}

본 절에서는 앞서 제시한 두 가지 원격조작기를 기준으로 


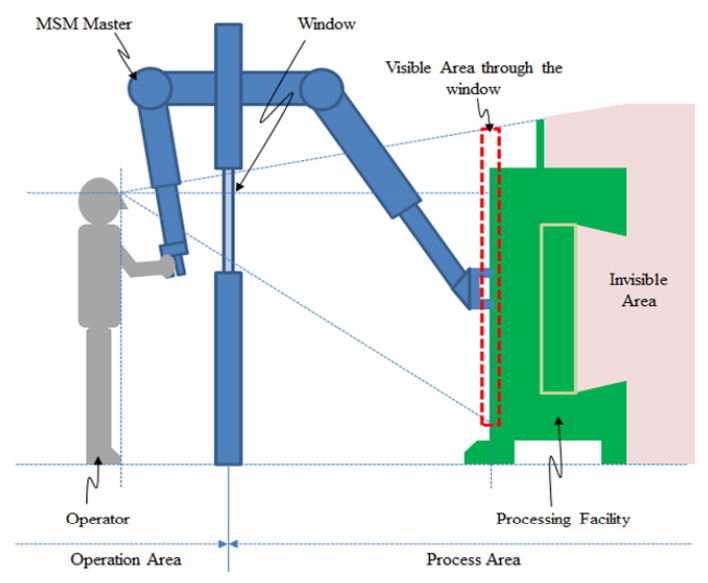

(a) Master-Slave Manipulator(MSM)

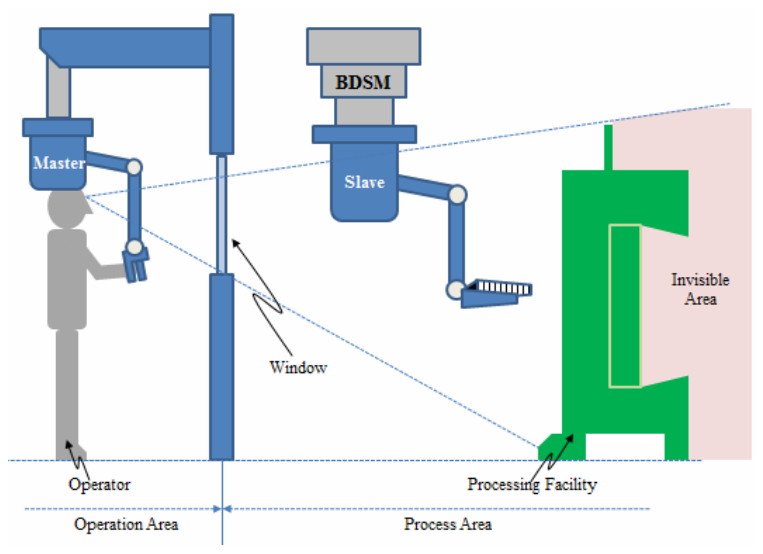

(b) Bridge-Transported Dual Servo Manipulator(BDSM)

Figure 2. Installed remote handling systems in PRIDE

하여 원격조작 시의 조작 편의를 도모하기 위한 몇 가지 고 려사항들을 제시하고자 한다.

\subsection{Arrangement of target facility based on the MSM operator's upper limb muscle forces}

원격조작기와 관련된 작업부하 측면에서, 본 연구에서 는 원격조작기를 조작하는 작업자에 대해 상지 (Upper Extremities)의 주요 동작범위 내에서 당기기, 밀기, 내리기, 올리기와 같은 전형적인 조작동작에 대한 작업자의 근력변 화에 주목하였다.

위와 같은 조작동작들의 유효근력은 팔꿈치 각도에 의하 여 영향을 받게 되는데, 이러한 관계는 Figure 3 과 같다 (Pulat, 1992). 이러한 관계를 PRIDE에서 운용되는 MSM 의 Master를 조작하는 동작에 적용할 경우, 팔꿈치가 펴질
수록 상하 방향의 하중물 취급에 불리하며, 팔꿈치의 각도가 90도 미만으로 몸통(Torso) 가까이에서 굴곡되어 있을 경 우, 전후 방향으로 밀고 당기는 동작에 불리하다는 것을 알 수 있다. 따라서, Figure 4에서 정의한 원격조작기의 조작동 작 및 팔꿈치 각도에 따른 유효근력과의 관계를 기준으로 하 였을 때, 원격조작 대상장치의 원격 취급부의 경우, Figure 5 와 같이 작업창으로부터 멀리 떨어진 지점에서 수직 방향으 로 가해지는 고하중물 인양, 억지 끼움 및 공구 취급 작업 등은 작업부하가 크고, Figure 6의 경우와 같이 작업창과 가 까운 지점의 경우에는 작업창 수직 방향으로 가해지는 억지 끼움 및 고하중물의 수평 방향 밀기/당기기 등의 작업이 부 하가 크다는 것을 알 수 있다. 이는 전술한 두 지점에서 조 작자가 취급해야 하는 Slave Arm의 Moment Arm이 극대 화된다는 측면에서 자명한 결과이다. 따라서 대상장치의 원 활한 운용을 위하여 이러한 사항들은 원격장치 설계 및 배치 시에 반드시 고려되어야 한다고 할 수 있다.

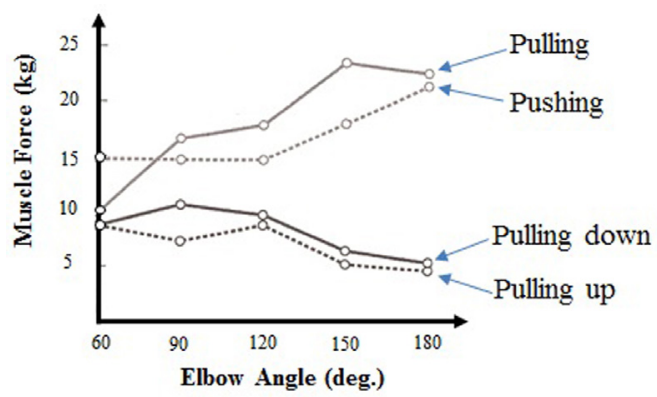

Figure 3. Variance of muscle force for various elbow angle (Pulat, 1992)

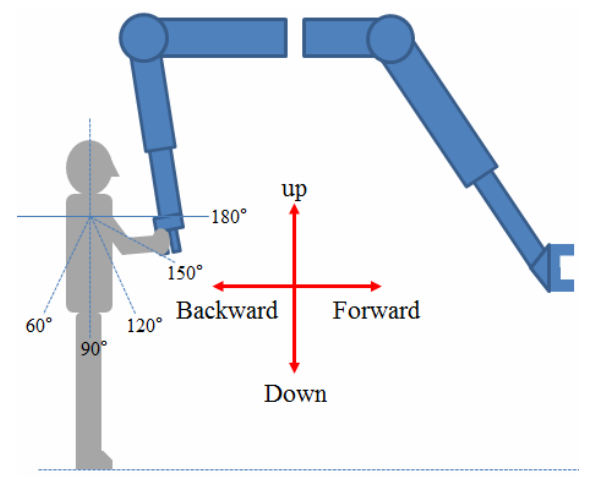

Figure 4. Four directions of exerted forces for a MSM

\subsection{Manipulation margin of MSM}

$\mathrm{PRIDE}$ 작업창 부근의 대상물을 취급할 경우, $\mathrm{MSM}$ 관절 


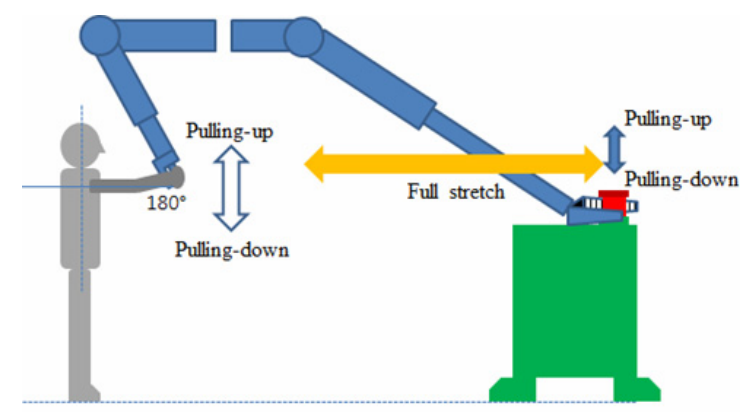

(a) Fully stretched MSM

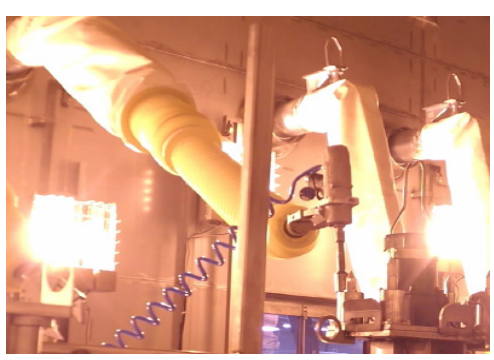

(b) Operator has to maintain his own position while handling the tool

Figure 5. One of the worst case of excessive motion: Manipulation of full stretched arm through the vertical direction

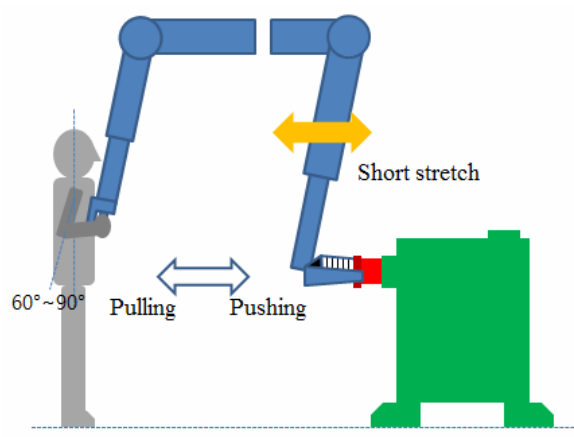

(a) Extremely folded MSM

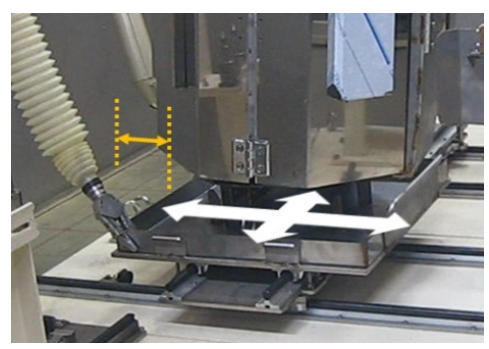

(b) Operator has to exert the large force to start the motion of the object near the MSM

Figure 6. Pushing the heavy plate(Example of Case 2)
중 가장 큰 동작범위를 가지는 직동관절(Prismatic Joint)이 최대 수축 상태에 가까우므로, 대상물에 대한 작업창 방향으 로의 추가적인 조작이 곤란하다. 따라서 원격 작업 대상장치 의 배치와 관련하여 간단한 연산을 통해 $\mathrm{MSM}$ 의 조작여유 (Manipulation Margin)를 제시하고자 한다. 이를 위하여 다 음의 가정을 따른다.
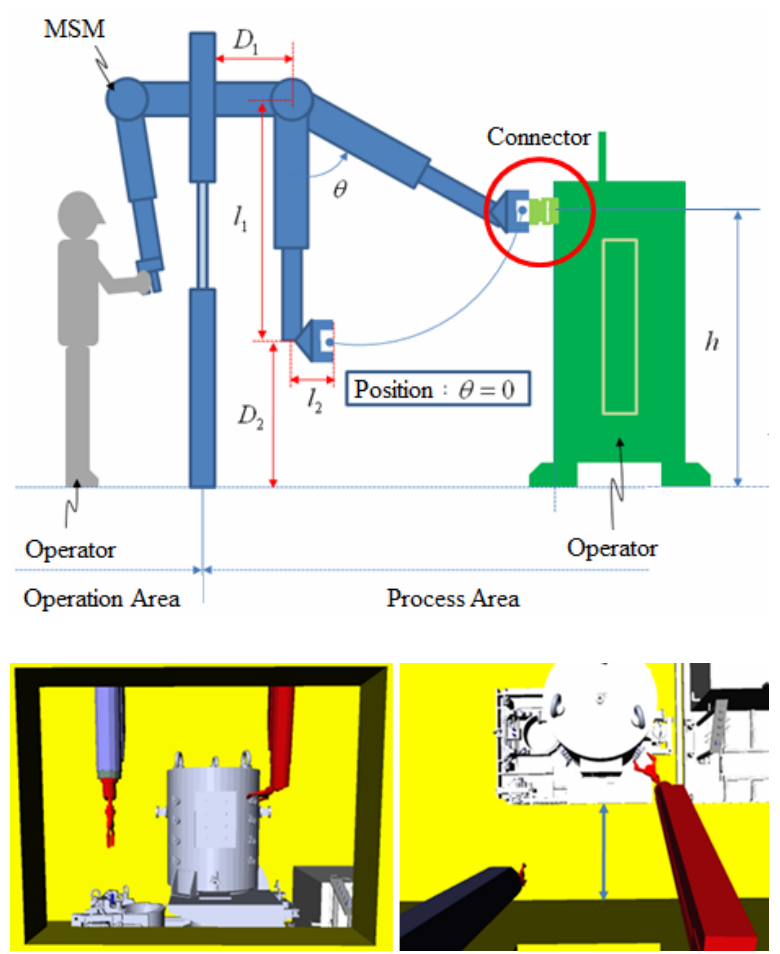

Figure 7. Basic parameters for a consideration of manipulation margin and a case of minimized manipulation margin (Manipulator tries to pull out a long thermocouple module toward a window but joints of manipulator are closed to a motion limit)

- 가정 1: 원격으로 공장장치 상에 연결된 커넥터를 분리/결 합하기 위해 MSM을 통한 모듈 파지 후, MSM의 자체 자 유도를 사용하여 후퇴할 수 있는 여유 공간이 필요한 경우 가 존재함

- 가정 2: 조작여유는 $\mathrm{MSM}$ 이 최소로 수축되어 있는 때(기 본자세, Figure 7 참조)에는 0의 값을 가짐

- 가정 3: 긴 형상을 가진 열전대의 분리 결합을 가정하여 $d_{m m}=500 \mathrm{~mm}$ 로 설정함

Figure 8과 같이, MSM 관련 변수들을 지정하여 공정장치 의 높이와 작업창을 기준으로 한 거리를 표현하면 다음과 같다. 


$$
\begin{aligned}
& h=\left(l_{1}-l_{1} \cos \theta\right)+D_{2} \\
& w=l_{1} \sin \theta+l_{2}+d_{m m}
\end{aligned}
$$
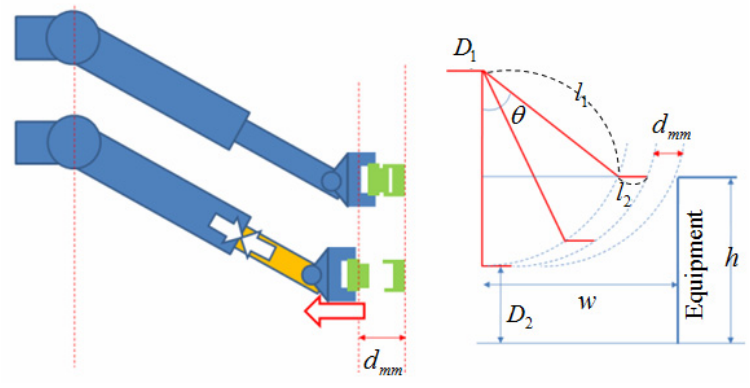

Figure 8. Manipulation margin of MSM to handle the front side of the target equipment

식(2)를 다음 식(3) 과 같이 변환하고 삼각함수 공식을 활용하면 식(4)와 같이 표현할 수 있다.

$$
\begin{aligned}
& \frac{w-l_{2}-d_{m m}}{l_{1}}=\sin \theta \\
& \sqrt{1-\left(\frac{w-l_{2}-d_{m m}}{l_{I}}\right)^{2}}=\cos \theta \\
& \left(0 \leq \theta \leq 90^{\circ}\right)
\end{aligned}
$$

식(4)를 식(1)에 대입하면,

$$
h=\left(l_{1}-l_{1} \sqrt{1-\left(\frac{w-l_{2}-d_{m m}}{l_{1}}\right)^{2}}\right)+D_{2}
$$

위의 식에 대해서, PRIDE MSM의 실제 치수인 $l_{1}=1378.8, l_{2}=183.5, D_{1}=654, D_{2}=1648$ (단위: $\mathrm{mm}$ ) 로 각각 설정하였을 때, Figure 7 과 같이 장치 전면부 최상 단에 위치한 열전대의 높이를 $h=1700 \mathrm{~mm}$ 라 하면 $w$ 는 다음과 같이 결정된다.

$$
w=642.43 \mathrm{~mm}
$$

여기에, MSM의 Over-hang distance인 $D_{1}=654 \mathrm{~mm}$ 를 더하면,

$$
\begin{aligned}
W & =w+D_{1}=642.43+654=1296.43 \\
& \cong 1300 \mathrm{~mm}
\end{aligned}
$$

위의 과정을 통해, 해당 공정장치의 작업창으로부터의 적 정 이격 위치 $W$ 를 산출할 수 있다. 따라서 본 공정장치의 전면부 $1700 \mathrm{~mm}$ 높이에 장착된 커넥터의 원활한 분리/결 합 작업을 위해서는 최소한 작업창으로부터 $1300 \mathrm{~mm}$ 이상 장치가 떨어져 있어야 함을 알 수 있다.

\subsection{Visibility analysis for the inside of a cell}

\subsubsection{Utilization of an eye-in-hand camera for remote handling tasks}

본 연구에서 제시된 $\mathrm{BDSM}$ 의 경우, 셀 내에서 $\mathrm{MSM}$ 이 도 달할 수 없는 장치 후면 및 장치 상부를 대상으로 한 원격 취급을 주로 수행하도록 고안되어 있다. 따라서 시스템의 특 성상, 조작자와 동일한 몸통 자세를 유지하는 경우는 많지 않고, Figure 9 와 같이 조작자와 서로 마주보는 위치에서 주 로 작업을 수행하게 된다. 다수의 실험자를 통해 반복적으 로 수행된 동작테스트를 통해서 이러한 상황은 직관적인 조 작이 곤란한 상황임을 파악할 수 있었으며, 이를 극복하기 위해 본 연구에서는, $\mathrm{BDSM}$ 그리퍼 주변 물체에 대한 근접 관찰용 장치인 $\mathrm{Eye}-\mathrm{in}-\mathrm{hand}$ 카메라의 활용을 시도하였다. Figure 10은 PRIDE 셀 내에 설치된 전해 환원장치의 전 극을 장입하는 작업에서, 작업창을 통한 육안 확보 대신, $\mathrm{BDSM}$ 왼팔의 Eye-in-camera를 통해 3인칭 시점의 시야 를 확보하고, 나머지 오른팔을 사용하여 전극을 장입하는 작 업 사례를 나타내고 있다. 이러한 조작방식을 통해, Figure 9 와 같이 Master를 조작하는 작업자의 오른팔과, 전극을 장 입하는 Slave의 오른팔이 일치시킴으로써 작업자의 직관적 인 작업이 가능하였다.

\subsubsection{Utilization of a digital mock-up system}

$\mathrm{PRIDE}$ 셀 내부에 설치되는 모든 공정장치들은 서로 간의 연계성을 가지고 있다. 즉, 공정의 흐름에 따라서 각 장치별 공정 산출물이 인접 혹은 후속 연계장치로 이송되는 구조를 가지고 있는 것이다. 따라서 각 공정장치의 횡 방향의 배치 순서는 본 연구의 고려 대상이 아니다. 하지만, 작업창과 공 정장치 간의 거리, 즉 종 방향의 배치는 공정장치에 대한 조 작기의 접근성 및 작업창을 통한 시야 확보 등의 측면에서 신중하게 고려되어야 한다. 따라서 본 연구에서는 Figure 10 과 같이 PRIDE 환경을 모사한 디지털 목업(Digital Mock-up)을 통해 각 장치의 원격 접근성, 가시성 분석 및 각 장치가 가진 물리적 제약사항 등을 종합적으로 고려하여 장치의 위치를 선정하였다. 디지털 목업에 대한 자세한 사항 


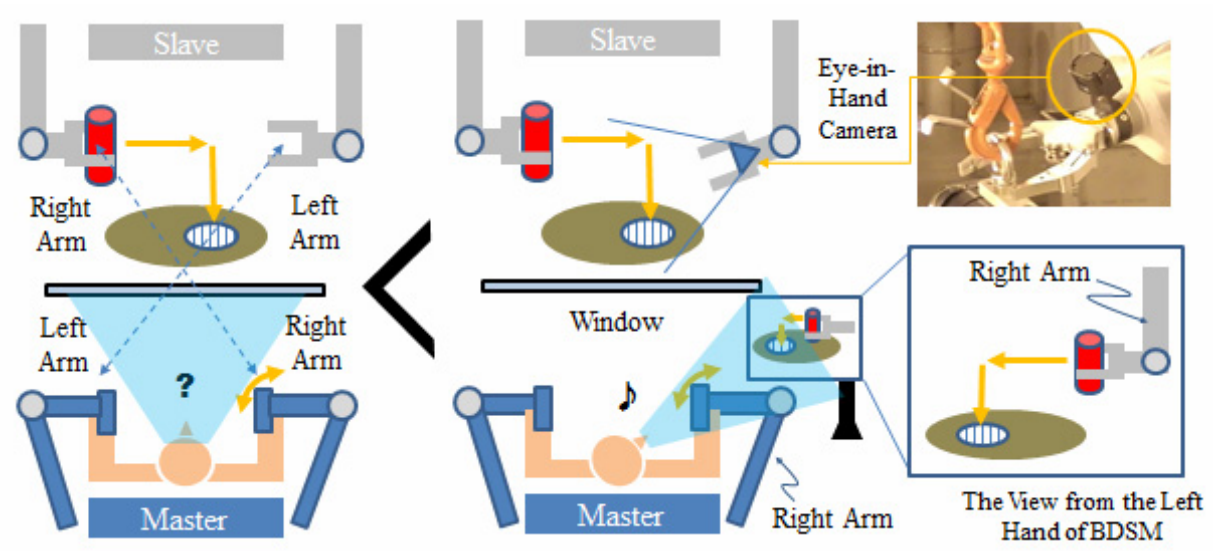

Figure 9. Considered operation strategy for the manipulation of BDSM using the eye-in-hand camera of grippers
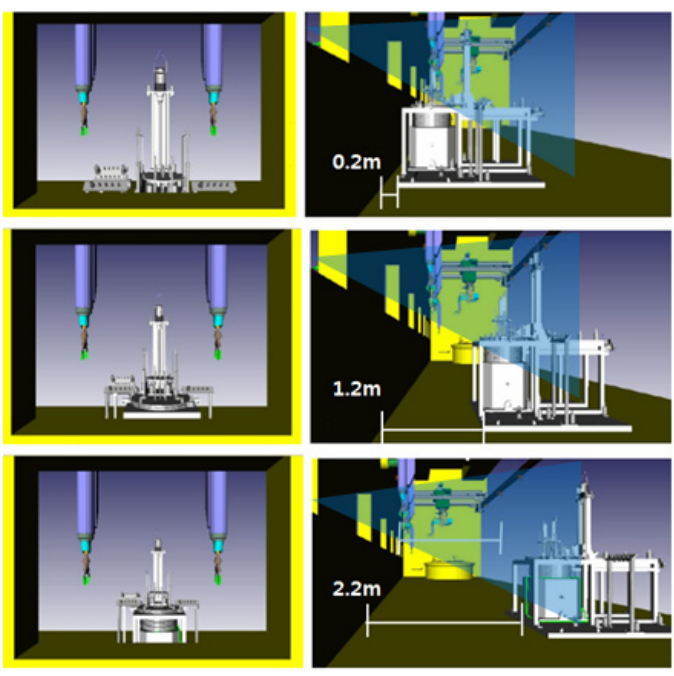

Figure 10. Visibility of equipment for the variation of distance from the window

은 $\operatorname{Kim}(2012)$ 의 연구를 참조하기 바란다.

\section{Tool Modification for Remote Handling Tasks in PRIDE}

PRIDE 원격조작기는 셀 내부에 위치한 공정장치의 운전 을 보조하거나 유지보수를 수행할 때 주로 사용된다. 이때 원격조작기와 주로 함께 활용되는 장비는 셀 내부의 천장에 설치된 크레인이다. 크레인의 말단부에는 대상물과의 연결 및 인양을 위한 후크(인양고리)가 마련되어 있는데, 이러한
후크의 결합 및 분리는 원격조작기가 셀 내부 원격 작업 시에 가장 빈번하게 수행하는 작업 중의 하나이다. Figure 11 (a)의 좌측과 같이 기존의 일반 후크는 고리에 체결하기 위해서는 원격조작기를 통해 후크 전체를 과도하게 회전시 켜야 하므로 원격조작기 조작자의 작업부하가 크다고 할 수 있다. 또한 후크 분리 시에는 후크의 이탈방지를 위해 부 착된 Snap을 개방한 상태로 후크를 분리해야 하기 때문에 원격조작기로 수행하기에는 매우 곤란한 작업이다. Figure 11 (a)의 우측은 이러한 문제를 개선하기 위해 제안한 방식 으로서, 후크를 걸기 위해 Snap을 개방하는 방식이 아닌, 후 크 하부 전체를 개방하는 방식으로 기계적 구조를 변경하는

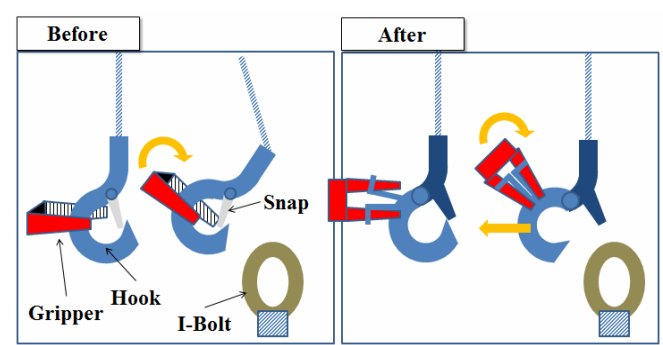

(a) Modified design of the fook for MSM

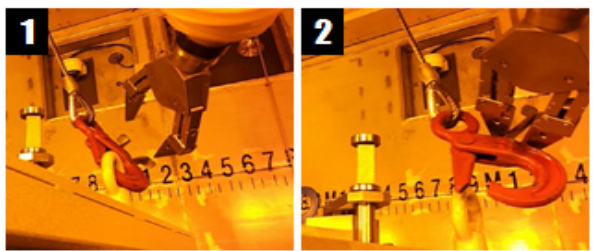

(b) Performance verification of the modified hook

Figure 11. Modified design of the hook 
한편, 후크 후면부에 별도의 파지부를 마련하여 후크의 개방 과 체결을 동일한 취급방식과 작업부하로 수행할 수 있도록 고안한 것이다. Figure 11(b)의 조작 실험을 통해 수정된 후크의 성능을 실증하였다.

또한, 작업창 외부로부터 정확한 삽입 각도와 삽입구 식별 이 곤란한 소형 플러그의 체결 및 분리 작업을 위해 플러그 에는 Figure 12 와 같이 가이드를 설치하였으며, 볼트 체결 용 공구의 경우에는 Figure 13 과 같이 회전축과 파지 방향 을 서로 수직으로 하여, 장치 결합용 볼트를 천장을 바라 보 는 방향으로 배치하였다. 이는 분리 대상 모듈의 대부분이 크레인으로 인양되기 때문에, 이송 경로가 대부분 수직 방향 이라는 점에 기인한 것이다.

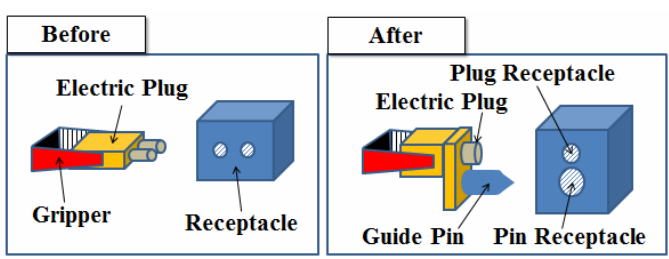

Figure 12. Modified design of the plugging system

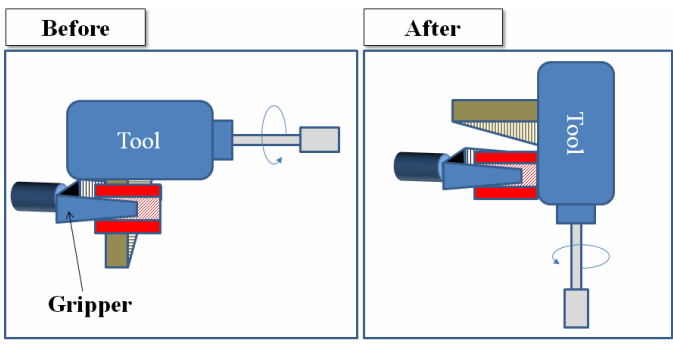

Figure 13. Modified design of the tool system

Figure 14는 조작기 손목부의 반복적인 자세 바꿈을 통한 회전을 필요로 하는 기존의 십자형 손잡이를, 손잡이 파지 후 한 방향의 수평 회전만으로 잠금과 풀기를 수행할 수 있 는 방식으로 개량한 사례를 도시하고 있다. 이를 통해 원격

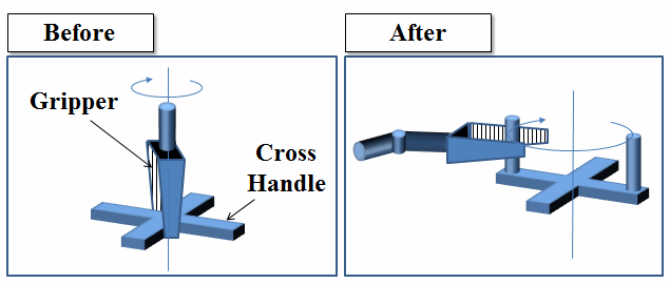

Figure 14. Modified design of the cross handle
조작기 조작자는 손목의 피로를 최소화 할 수 있다.

\section{Performance Verification of Remote Handling Tasks}

\subsection{Remote handling test for the PRIDE facility}

$\mathrm{PRDIE}$ 에 설치된 주요 공정장치들은 각각 전해환원, 전해 정련, 전해제련 및 염폐기물 공정 등을 담당하게 되며, 대부 분의 장치는 공통적으로 전동 구동부를 가지고 있다. 하지만 이러한 모듈들은 장치 운전과정에서 고장 등의 이유로 교체 의 필요성이 발생한다. 본 절에서는, 전 장에서 제시된 원격 취급 기구들이 적용된 다양한 형태의 전동기 모듈들에 대한 원격 분리 및 결합 작업을 수행한 결과를 정리하고, 작업별 소요 시간을 측정하여 비교 분석하였다. 아울러, 좁은 공간 에서 원격 취급 작업을 수행해야 하는 큰 체적의 케이스 모 듈에 대한 원격교체 작업 시간도 함께 측정하였다. Figure 15 는 이러한 실험 결과를 도시하고 있으며, 세 가지 종류의 서로 다른 결합방식을 가진 전동 구동부 모듈 및 장치 케이 스 모듈에 대한 원격 분해, 반입/반출 및 원격 결합 작업의 구간별 소요 시간을 나타내고 있다. 본 테스트를 수행한 원 격조작기 조작자는 시스템 조작방식을 잘 이해하고 있으며 반복 사용을 통한 조작 숙련도의 향상 여지가 있는 중급 수 준의 조작자로 간주한다. 전동 구동부 모듈 Type 1 의 경우, 분리된 모터 모듈을 재결합하는 과정에서 크레인을 통한 수 평/수직 이동이 모두 필요한 작업 경로를 요구하는 관계로, 모듈을 목표 위치에 접근시키기 위한 원격조작기의 빈번한 개입이 불가피하였다. 특히, 작업창으로부터 가장 멀리 떨어 진 지점에 작업 위치가 존재하기 때문에 작업창을 통한 직접 적인 시야 확보가 곤란하여 $\mathrm{BDSM}$ 의 Eye-in Hand Camera 에 의존한 작업이 이루어졌다. 이로 인하여 모듈의 목표 지 점에 대한 정위치 작업에 많은 시간이 소요되었다. 전동 모 듈 Type 2의 경우, MSM을 통한 볼트 체결부 해체는 원활 하였으나, 원격 취급성을 개량하지 않은 일반 후크를 사용함 에 따라, 모듈 인양을 위한 인양고리 체결에 많은 시간을 소 비하였다. 모듈 Type 3 의 경우, 수평 방향의 밀어넣기 동작 이 필요한 Type 1 에 비하여 훨씬 짧은 작업 시간이 소요되 었으며 분리 및 결합 작업이 대체로 원활하였으나, 모듈 부 속 케이블의 적절한 선처리 등은 개선되어야 할 것으로 파 악되었다.

\subsection{Considerations and experimental results}

이러한 원격 취급 작업의 결과를 바탕으로 MSM 및 


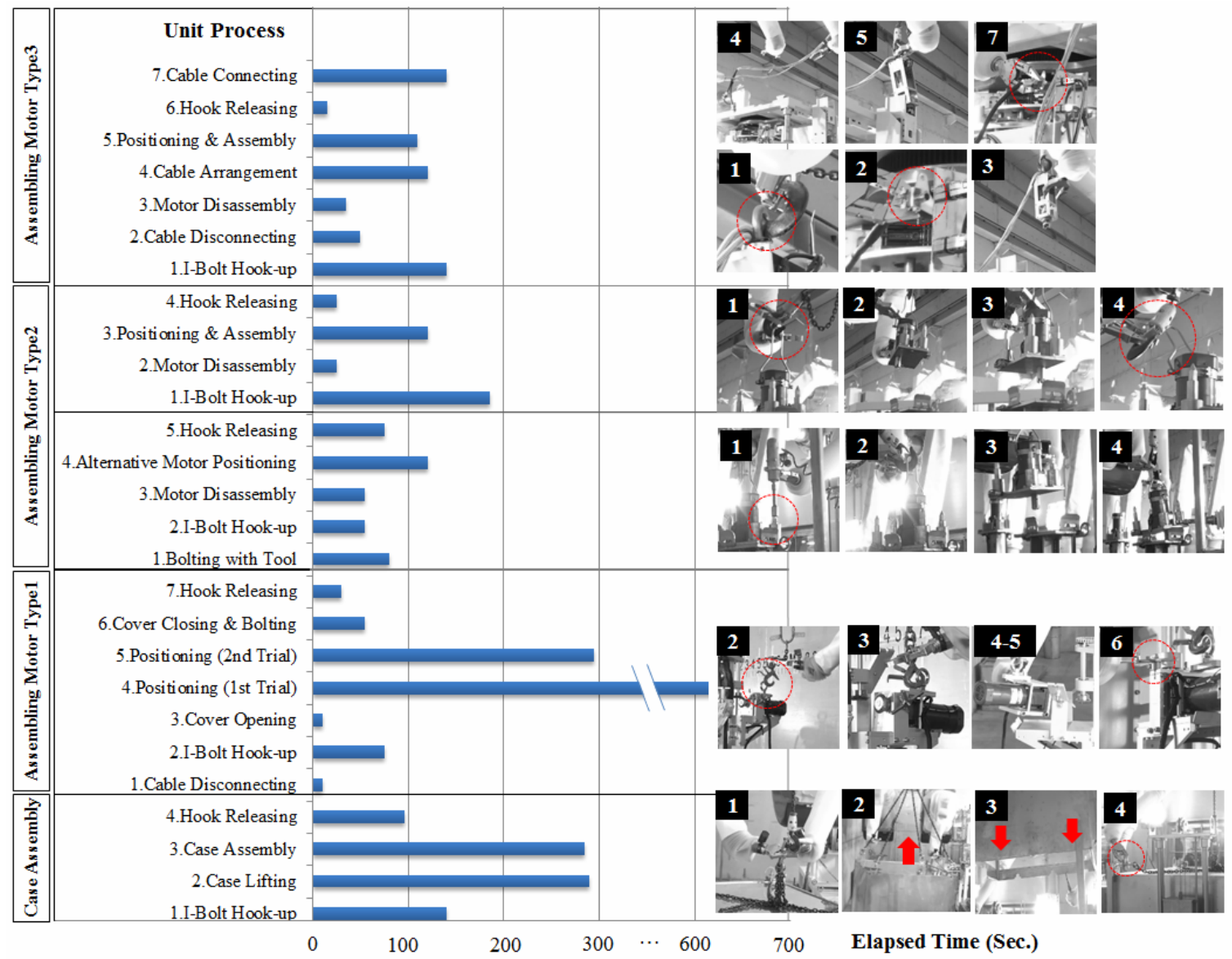

Figure 15. Elapsed time for each case of remote handling task

$\mathrm{BDSM}$ 을 이용한 PRIDE 셀 내에서의 원격 취급 작업에 대 한 잠정적 결과를 정리하면 다음과 같다. 첫째, $\mathrm{MSM}$ 의 경우, 작업창 상부에 고정된 방식으로서 Master를 조작하는 작업 자 상지의 방향과 Slave의 방향이 항상 일치하여 직관적인 운전이 가능하였다. 하지만 BDSM의 경우, Master-slave 운전 자체를 위한 근력 부담은 적은 편이지만, 다양한 작업 을 수행할 목적으로 몸통의 자세가 수시로 변경될 수 있는 특성이 있다. 따라서 작업창을 통한 직관적인 조작이 곤란한 구조이므로, 작업 공간이나 조작기 자체에 마련된 보조 카메 라를 적극 활용하여 모니터를 통한 시야 확보를 병행하는 것 이 중요하였다. 둘째, 원격조작기를 통해 케이블 커넥터를 취급할 경우, 조작자가 파지된 커넥터의 자세 및 진입 각도 를 작업창 외부에서 정확하게 인지하기 어려운 경우가 빈번 하게 발생한다. 따라서 대상물을 목표 지점에 결합할 경우, Female-male 결합지점에 Guide bar를 마련하여, 지근 거 리 접근만으로 자중이나 Guide의 형상 특성에 의해 자연스 럽게 결합이 마무리되도록 하는 것이 원격 취급 작업에 유
리하였다.

\section{Conclusions and Future Works}

원격조작은 일반작업부하에, 원격 매니퓰레이터 취급부하 및 이를 이용한 공정장치 취급부하가 결합된 복합적인 작업 이라고 할 수 있다. 본 연구에서는 격리된 셀 내부에 설치된 이러한 공정장치들을 대상으로 운용되는 원격조작기의 취급 에 용이한 장치 배치를 제안하고 아울러 원격조작기와 협업 하는 부대장치 및 공구들을 개량하여 시설에 적용하였다. 최 종적으로는 이들 원격 취급 장비들을 사용하여 PRIDE에 설 치된 공정장치 부속 모듈들에 대한 원격 분리/결합 실험을 수행하여 단위 작업별 소요 시간을 측정하고 작업성을 평가 하였다. 향후에는, 공정의 실시간 운전상황에 대응하여 다수 의 조작자를 대상으로 한 원격조작기 운전의 인간공학적 작 
업부하를 추가로 고찰해 보고자 한다. 또한 $\mathrm{BDSM}$ 의 천정이 동장치 컨트롤러 및 Master의 사례와 같이, 동시 조작이 필 요한 복수의 입력 수단에 대한 접근성 및 휴대성을 개량하여 시스템 가동 중의 조작자의 시선 분산을 최소화하고 작업효 율을 극대화할 수 있는 조작 편의성 측면의 연구도 진행할 예정이다.

\section{Acknowledgements}

This work was supported by Nuclear Research \& Development Program of National Research Foundation of Korea(NRF) funded by Ministry of Education, Science \& Technology(MEST).

\section{References}

Babur M. Pulat, Fundamentals of Industrial Ergonomics, Prentice Hall Inc., 1992.

Internet Website: http://www.hwm.com/12-1-Master-Slave+Mani pulator+ Typen+A100.html (Accessed 22 May, 2012).

Kim, Ki-Ho, "Evaluating remote operability and maintainability of pyroprocessing equipments", The 18th Pasific Basin Nuclear Conference, 2012.

Kim, Ki-Ho, Lee, Jong-Kwang, Park, Byung-suk and Cho, Il-je, "PRIDE Remote Handling Systems", 2012 12th International Conference on Control, Automation and Systems, (pp.2203-2206), Korea, 2012.

Lee, Han-Soo, "Development of Pyroprocessing Facilities Technology", Nuclear Industry, March-April, 91-117, 2009.

Lee, Jong-Kwang, Lee, Hyo-Jik, Park, Byung-Suk, Yu, Seung-Nam, Kim, Ki-Ho and Kim, Ho-Dong, "Bilateral control of master-slave manipulator system using time delay control", Int. Conf. on Informatics in Control, Automation and Robotics, (pp.37-42), Nederland, 2011.

Mark J. Rennich, Thomas W. Burgess, "Remote handling in the Spallation Neutron Source target facility", Robotics and Remote Systems Special Section of Nuclear News, 2006.

Pete C. Pittman, Jeffrey E. Roybal, Russell E. Durrer, Derek J. Gordon, "Material Handling For the Los Alamos National Laboratory Nuclear Storage Facility", Robotics and Remote System 8th Int. Topical Meeting and exposition, 1999.

Yu, Seung-Nam, Kim, Sung-Hyun, "Experimental Study of Remote Handling Performance for Pyroprocessing Facilities", Transaction of Korean Society for Precision Engineering, 29(5), 524-530, 2012.

\section{Author listings}

Seung Nam Yu: snyu@kaeri.re.kr

Highest degree: $\mathrm{PhD}$, Department of Mechanical Engineering, Hanyang University

Position title: Senior Researcher, Remote System Technology Development Section, Korea Atomic Energy Research Institute Areas of interest: Wearable robot, Teleoperation system

Jong Kwang Lee: leejk@kaeri.re.kr

Highest degree: $\mathrm{PhD}$, Department of Mechanical Design Engineering, Chungnam National University

Position title: Senior Researcher, Remote System Technology Development Section, Korea Atomic Energy Research Institute Areas of interest: Remote handling system for hot-cell application, Machine intelligence

Sung Hyun Kim: hyun@kaeri.re.kr

Highest degree: $\mathrm{PhD}$, Department of Computer Engineering, University of Hannam

Position title: Principal Researcher, Remote System Technology Development Section, Korea Atomic Energy Research Institute Areas of interest: Design for spent fuel handling and hot-cell maintenance, Graphic simulation for remote handling system in hot-cell

Byung Suk Park: nbspark@kaeri.re.kr

Highest degree: $\mathrm{PhD}$, Department of Mechanical Design Engineering, Chungnam National University

Position title: Principal Engineer, Remote System Technology Development Section, Korea Atomic Energy Research Institute Areas of interest: Design and control of remote systems, Force reflection, Signal processing

\section{Ki Ho Kim: khkim5@kaeri.re.kr}

Highest degree: $\mathrm{PhD}$, Department of Mechanical Engineering, Iowa State University (USA)

Position title: Principal Engineer, Remote System Technology Development Section, Korea Atomic Energy Research Institute Areas of interest: Design and control of remote systems and robotics, Telerobotics, Teleoperation

\section{Il Je Cho: hyilje@kaeri.re.kr}

Highest degree: M.S, Department of Nuclear Engineering, Hanyang University

Position title: Senior researcher, Remote System Technology Development Section, Korea Atomic Energy Research Institute Areas of interest: Design of nuclear fuel cycle facility and remote handling system 
Date Received : 2013-01-14

Date Revised : 2013-01-21

Date Accepted : 2013-01-25 